\title{
The Assessment Model of Undergraduate Mathematics and Science Education Competency Based on Indonesian National Qualification Framework and $21^{\text {st }}$ Century Demand
}

\author{
Wasis \\ Physics Department, Faculty of Mathematics and Natural Science, Universitas Negeri Surabaya \\ wasis@unesa.ac.id \\ Raden Sulaiman \\ Mathematics Department, Faculty of Mathematics and Natural Science, Universitas Negeri Surabaya \\ radensulaiman@unesa.ac.id \\ Elok Sudibyo \\ Science Department, Faculty of Mathematics and Natural Science, Universitas Negeri Surabaya \\ Bertha Yonata \\ Chemistry Department, Faculty of Mathematics and Natural Science, Universitas Negeri Surabaya \\ Muji Sri Prastiwi \\ Biology Department, Faculty of Mathematics and Natural Science, Universitas Negeri Surabaya
}

\begin{abstract}
This article reports the competency profile of undergraduate Mathematics and Natural Science education based on Indonesian National Qualification Framework (INQF) and 21 st century demands, and its assessment model. The competency profile was formulated based on theoretical and regulation reviews. The profile developed covers generic competencies based on INQF main indicators and specific competencies with mastery learning, 4C Skills (critical thinking, creative thinking, communication, and collaboration) characteristic, TPACK (technological, pedagogical, and content knowledge) implementation in teaching-learning process, and implementation of self assessment. Competency assessment model that has been developed is designed to measure competency achievement of prospective teacher comprehensively and implemented using computer-based test (CBT). The results of the study of experts in the focused-group discussion (FGD) are known that in substance and language, the competency test model has been oriented INQF and 21 st century needs but has not fulfilled the construction of simple, practical, and easy test model in making practical test of competence test.
\end{abstract}

Keywords - competency profile, bachelor degree of education MIPA, KKNI, XXI Century, competency test model.

\section{INTRODUCTION}

Twenty first century demands changes, triggered by rapid technology development and as well as remarkable developments in science, technology, psychology, and the transformation of cultural values. Twenty first century is new millennium marked by new era called velocity era or smart technology era, in which is information, decision, and action occur quickly. Globalization and free trade, AFTA, AFLA, and APEC have been ignited free trade formation and tight competition for goods and services. The strength, endurance, and global competitiveness of a country will not be determined by natural source richness, but will be determined by ability, creativity, and skills of human sources. Therefore, education should be able to play a role to improve quality and relevance of their graduates to face global challenges.

Twenty first educations will be not enough if only focuses on core subject as it have happened at last centuries. Teaching and learning in preparing human sources context has to equip with higher order thinking skills and able to create learning ability [1]. It is not only to gain knowledge, skills, and 
attitudes, but also to use the knowledge, skills, and attitudes to solve problem in real life.

The shift in education paradigm explained before also implies a shift in learning from learning that focuses solely on mastery of knowledge into holistic learning based on skills, value equilibrium, and ICT [2]. Teachers as teaching and learning manager finally have to revitalize themselves, change their mindset from "teachers and what they teach" to "students and what they do". Besides developing themselves as $21 \mathrm{st}$ century demands, teachers also have to upgrade their competencies so that they are able to equip students to follow or anticipate the development of the era.

The Government of Indonesia mandates qualification of competencies formulated as the Indonesian National Qualification Framework (INQF). INQF is pairing, balancing, and integrating competencies among education and work training, and also work experiencing to give a competence recognition in several sectors. Based on INQF, undergraduate students are in level 6, and also education undergraduate students [3].

Although qualification framework is already formulated, in fact, the quality of undergraduate students who are already as teachers have not showed their competencies as it hoped. This fact can be seen from teacher monitoring and evaluation in junior high school in 2014. There were $55 \%$ of teachers who are able to compile teaching and learning plan, there were $47 \%$ of teachers who are able to conduct learning activity, there were $39 \%$ teachers who have understanding of assessment-including developing assessment instruments, and there were $33 \%$ of teachers who are able to conduct assessment [4]. It can be seen from average achievement of teachers who teach mathematics and science in teacher competence testing that is still below passing grade, 71.36. There were only $2 \%$ of teachers that achieved over passing grade $(\geq 80)$.

For that reason, it is necessary to analyze theoretically and comparatively the undergraduate education students' competencies by paying attention on 21 st century demand. Higher education institution producing teachers in Indonesia are also to evaluate themselves to ensure that their graduates already achieve targeted competencies. It also needs to develop competence testing model for education undergraduates that are able to assess learning outcomes comprehensively.

Based on the description mentioned, there are two important questions, first: how is the essential competency profile of mathematics and natural science education of undergraduate as 21 st century and INQF demands; second: how is competency assessment model that is valid to assess education undergraduate competency?

\section{METHOD}

In this research, competency profile was formulated based on theoretical and regulation reviews. The profile covers generic competencies based on INQF main indicators and specific competencies with mastery learning, 4C Skills characteristic, TPACK implementation in mathematics and sciences teaching-learning process, and implementation of self assessment. To develop competency profile it is necessary to develop competency assessment model. Focus Group Discussion is needed to find the feasibility of the model. Results of competency test model review were conducted through Focused-Group Discussion (FGD) followed by 15 experts consisting of expert of assessment, substance and regulation.

In FGD, 15 experts filled the questionnaire about competency assessment model. The questionnaire asked about substance (qualify ability and skill from level 6 according to INQF and the competency test model contains the elementary needs of 21st Century teachers), construction, and language. The experts chose yes, no, or no argument in the questionnaire about competency assessment model. The results of competency assessment model review were obtained. The results of the study were used to improve theoretical model of competency test, whether it has tested the competency test model of Mathematics and Natural Sciences oriented graduate education and the needs of $21^{\text {st }}$ Century teachers.

\section{RESULT AND DISCUSSION}

\section{A. Profile of Teacher Competency of Mathematics and Natural Science}

Based on the results of the literature review and the above regulation, some findings were obtained. First, teacher competences can be formulated in four domains: a) teacher's mastery of substance (b) teacher skills encapsulate learning that facilitates optimal learning, c) teachers' ability to develop themselves as educators and learners, and d) teacher's ability to participate in social life. [3], [5], [6], [7]

Undergraduate education aims to prepare teachers candidate to be a professional teacher who has four teacher competencies above. Because the task of the teacher is to facilitate the students in learning, then the teacher should always develop himself so that the students' learning outcomes also according to the development of the era. The importance of 4C skills (critical thinking, creative and innovative skills, communication and collaboration) in the life of the present century [2], [8], [9], [10], and [11] and apply TPACK (technological, pedagogical, and content knowledge) in planning and implementing teaching and learning [12], [13]. Therefore, it is necessary to formulate a specific LO description in INQF for undergraduate education of Math and Natural Science by considering the formulation of teacher competence and $21^{\text {st }}$ century demand, presented in Table 1. 
TABLE I. UNDERGRADUATE OF EDUCATION OF MATHEMATICS AND NATURAL SCIENCE COMPETENCES ORIENTED INQF AND DEMANDS OF THE $21^{\text {ST }}$ CENTURY

\begin{tabular}{|c|c|c|}
\hline & INQF Indicators & $\begin{array}{l}\text { Specific Indicators for Mathematics and } \\
\text { Sciences Education Undergraduates }\end{array}$ \\
\hline & $\begin{array}{l}\text { Mastering the } \\
\text { substance r of } \\
\text { Mathematics and } \\
\text { Science in depth } \\
\text { along with the } \\
\text { learning process } \\
\text { and able to } \\
\text { formulate problem } \\
\text { solving } \\
\text { procedurally }\end{array}$ & $\begin{array}{l}\text { 1. Mastering the concepts, principles, laws, } \\
\text { theories, and processes or procedures in the } \\
\text { field of mathematics and science thoroughly } \\
\text { (mastery learning) } \\
\text { 2. Analyze essential matter and pack it in } \\
\text { effective learning } \\
\text { 3. Mastering various learning theories, } \\
\text { characteristics of learners, planning (including } \\
\text { device development) and application of } \\
\text { learning, as well as evaluating and utilizing } \\
\text { learning outcomes polving, } \\
\text { 4. Formulate and implement problem solving } \\
\text { especially procedural learning problem } \\
\text { through scientific approach. }\end{array}$ \\
\hline & $\begin{array}{l}\text { Able to utilize } \\
\text { science and } \\
\text { technology in the } \\
\text { field of } \\
\text { Mathematics and } \\
\text { Learning and able } \\
\text { to adapt to the } \\
\text { situation faced in } \\
\text { solving } \\
\text { problem. }\end{array}$ & $\begin{array}{l}\text { 1. Utilize the development of science and } \\
\text { technology critically to renew the mastery of } \\
\text { MIPA substance } \\
\text { 2. Utilizing technology in an integrated way in } \\
\text { developing mathematics and science learning } \\
\text { tools in TPACK format (technological, } \\
\text { pedagogical, and content knowledge) } \\
\text { 3. Able to choose and use learning resources and } \\
\text { learning media based on science and } \\
\text { technology critically to support the } \\
\text { implementation of optimal learning }\end{array}$ \\
\hline & $\begin{array}{l}\text { Able to make } \\
\text { strategic decisions } \\
\text { based on } \\
\text { information and } \\
\text { data analysis, and } \\
\text { provide guidance } \\
\text { on choosing } \\
\text { different solutions }\end{array}$ & $\begin{array}{l}\text { 1. Able to analyze information and data } \\
\text { critically to determine alternative solutions } \\
\text { in making strategic decisions } \\
\text { 2. Able to design and carry out research } \\
\text { creatively to produce alternative problem } \\
\text { solving in the field of education } \\
\text { mathematics and science which results can } \\
\text { be implemented in the learning in the } \\
\text { classroom } \\
\text { Able to communicate the results of research } \\
\text { and development of mathematics and } \\
\text { science education in scientific forums }\end{array}$ \\
\hline D. & $\begin{array}{l}\text { Responsible for } \\
\text { the work itself and } \\
\text { can be responsible } \\
\text { for the } \\
\text { achievement of the } \\
\text { work of the } \\
\text { organization }\end{array}$ & $\begin{array}{l}\text { 1. Responsible for the achievement of } \\
\text { individual work } \\
\text { 2. Able to carry out the task and know the } \\
\text { consequences } \\
\text { 3. Be able to collaborate and take role } \\
\text { according to cooperative working function } \\
\text { 4. Able to conduct self-evaluation }\end{array}$ \\
\hline
\end{tabular}

\section{B. Competency Assessment Model}

For various learning outcomes or competency achievements, no single assessment method is able to present them all [14]. Each competency achievement requires an assessment method according to the characteristics of each competency, therefore various multi strategy methods should be used and various information must be collected to produce an accurate competency assessment.

Competency assessment model of undergraduate of Math and Natural Science Education consists of basic components, namely 1) Competency test objectives, where competency test aims to measure the achievement of the competence of math and natural science; 2) Competency test strategy is a series of ways/steps taken in measuring the competence of math and natural science; and 3) Feedback, that is feedback against competency test result that can be used by students and lecturers to improve learning and student performance. The scope of competence assessment of graduate of Math and Natural Science Education is shown in Table 2 and Figure 1.

TABLE II. COMPETENCY ASSESSMENT MODEL SCOUPE BASED ON INQF AND $21^{\text {ST }}$ CENTURY DEMANDS

\begin{tabular}{|c|c|c|c|}
\hline Indicator & $\begin{array}{c}\text { Testing } \\
\text { technique }\end{array}$ & Testing strategy & Time \\
\hline $\begin{array}{c}\mathbf{A}(\mathbf{1}, \mathbf{2}, \mathbf{3}) \\
\mathbf{B}(\mathbf{1}) \\
\mathbf{C}(\mathbf{1})\end{array}$ & Testing & $\begin{array}{l}\text { Paper based test or } \\
\text { CBT } \\
\text { Based on enriched } \\
\text { rubric of Teacher } \\
\text { Competency test } \\
\text { and } 21 \text { st century } \\
\text { skills } \\
\text { Test is also use to } \\
\text { diagnose } \\
\text { misconception }\end{array}$ & $\begin{array}{l}\text { Before thesis } \\
\text { testing at least } \\
\text { achieve } 80 \text { of scores, } \\
\text { if it not achieve the } \\
\text { minimal score there } \\
\text { will be retest }\end{array}$ \\
\hline $\begin{array}{l}\text { A (4) } \\
\text { B (2,3) } \\
\text { D (3) }\end{array}$ & $\begin{array}{l}\text { Performance } \\
\text { assessment }\end{array}$ & $\begin{array}{l}\text { Through PPP I } \\
\text { lecture } \\
\text { microteaching, and } \\
\text { teaching simulation } \\
\text { Through PPP II } \\
\text { lecture }\end{array}$ & $\begin{array}{l}\text { Observation in } \\
\text { campus } \\
\text { Observation in } \\
\text { school }\end{array}$ \\
\hline $\mathrm{C}(2,3)$ & Assignment & $\begin{array}{l}\text { Through research } \\
\text { method lecture, by } \\
\text { assessing students' } \\
\text { thesis proposal } \\
\text { Through seminar/ } \\
\text { colloquium lecture }\end{array}$ & $\begin{array}{cc}\text { As } & \text { lecture } \\
\text { schedule } & \end{array}$ \\
\hline $\mathrm{D}(1,2,4)$ & $\begin{array}{l}\text { Self } \\
\text { assessment }\end{array}$ & $\begin{array}{l}\text { Self evaluation } \\
\text { Check plagiarism } \\
\text { of thesis and } \\
\text { articles }\end{array}$ & $\begin{array}{l}\text { After } \\
\text { testing }\end{array}$ \\
\hline
\end{tabular}

The basic concepts and scope of the competency assessment model are presented in Figure 1 below.

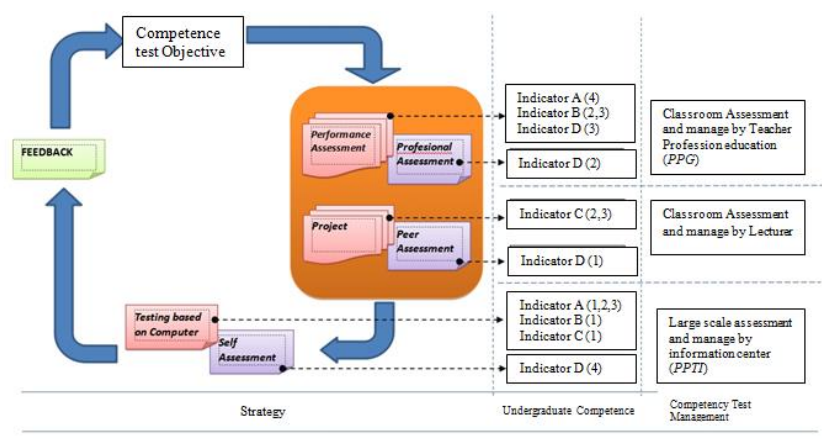

Figure 1. The basic concepts and scope of the competency test

The strategy used to measure the achievement of competence is the first strategy which consists of 1) performance assessment aimed at measuring the competence of formulating and implementing problem solving, especially procedural learning problem through scientific approach (A4), the ability to exploit science and technology development critically to renew the mastery of substance (B2), the ability to select and use learning resources and technology-based learning media critically to support optimal learning (B3), 
ability to communicate research results and development of math and natural science education in scientific forum (D3); and 2) assessment of partner teachers aims to measure ability to carry out the task and know the consequences (D2).

The second structure consists of: 1) the project aims to measure the ability to design and conduct research creatively to produce alternative problem solving in the field of math and natural science education whose results can be implemented in classroom learning $(\mathrm{C} 2)$, the ability to communicate research results and development of math and natural science education in the forum scientific (C3); and 2) peer assessment aims to measure the ability to take responsibility for the achievement of individual work (D1).

The third strategy, the computerized based test is aimed at measuring the mastery learning (A1) concept, principle, law, theory, and process (A1), the ability of analyzing essential matter and packing it in learning (A2), the mastery of various learning theories, the characteristics of learners, planning strategies (including device development) and the application of learning, as well as evaluating and utilizing learning outcomes (A3), the ability to exploit the development of science and technology critically to renew the mastery of math and natural science substance (B1), and the ability to analyze information and data critically to determine alternative solutions for making strategic decisions (C1); and self assessment aims to measure the ability to conduct selfevaluation (D4). Measurement results in the form of feedback on competency test results that can be used by students and lecturers to improve learning and student performance.

Review of the model was conducted through FocusedGroup Discussion (FGD) followed by 15 experts consisting of expert assessment, substance and regulation. The results of the study were used to improve theoretical model of competency assessment. The results are presented in Table 3

TABLE III. RESULTS OF COMPETENCY ASSESSMENT MODEL REVIEW

\begin{tabular}{|l|c|}
\hline \multicolumn{1}{|c|}{ Review Aspect } & Review Result (\%) \\
\hline A. Substance & \\
\hline $\begin{array}{l}\text { 1. } \\
\text { Qualify ability and skill from level 6 according } \\
\text { a. Mastering the substance and pedagogic of } \\
\text { Math and Natural Science }\end{array}$ & $82 \%$ \\
\hline b. The ability to make strategic decisions & $82 \%$ \\
\hline c. Responsible for the work & $70 \%$ \\
\hline 2. The competency test model contains the \\
elementary needs of 21 ${ }^{\text {st }}$ Century
\end{tabular}

Based on the Table 3, it can be seen that the competency assessment model seen from the substance oriented INQF and the needs of $21^{\text {st }}$ Century teachers has been fulfilled. This is based on the reviewers, where each aspect gets the percentage of agreement $\geq 70 \%$.

Suggestions are given for the improvement of aspects of substance and indicator of assessment. It should be not only knowledge but the essence of the nature of science, i.e. products (facts, concepts, principles, theories and laws); process (skill of science process with scientific method); and values (curiosity, objectivity, honesty, responsibility and others). In addition, the concept of knowledge needs to be clarified so as not to overlap level 6 and 7 INQF where level 7 is product of Teacher Education and Training, while the competency of graduate is at level 6. Competency assessment model must be completed as a practical instruction of the implementation.

\section{CONCLUSION}

The resulting profile includes generic competencies based on key indicators of INQF and specific competencies characterized by mastery learning, 4C skills (critical thinking, creative thinking, communication, and collaboration), TPACK (technological, pedagogical, and content knowledge), and self assessment. The competency assessment model developed ensures minimal comprehensive achievement and can be implemented with computer-based test. The competency assessment model has been oriented INQF and $21^{\text {st }}$ century demands and valid by expert judgment, but must be completed as a practical instruction.

It is important to conduct field tests to find out the practicality and effectiveness of the assessment model that has been developed.

\section{ACKNOWLEDGEMENT}

We acknowledge the generous support of the Government of Indonesia through the Directorate of Research and Community Service, which has funded this study through the competitive grants research scheme.

\section{REFERENCES}

[1] B. Joice and M. Weil, Model of Teaching, Boston: Allyn and Bacon, 1996.

[2] Partnership for 21st Century Skills, Framework for 21st Century Learning, (www.p21.org), 1996.

[3] Kemendikbud, Peraturan Presiden Republik Indonesia Nomor 8 Tahun 2012 Tentang Kerangka Kualifikasi Nasional Indonesia, Jakarta: Kemendikbud, 2012.

[4] Direktorat PSMP, Laporan Monitoring dan Evaluasi Implementasi Kurikulum 2013 pola klaster, Jakarta: tidak diterbitkan, 2014.

[5] F. Caena, "Literature review teachers' core competences: requirements and development", European Commission, 2014

[6] Department of Education and Training of Western Australia, Competency framework for teachers, Australia: Royal Street East Perth Western Australia, 2004.

[7] R. I. Arend, Learning to teach (5 $5^{\text {th }}$ ed.), Boston: McGraw-Hill Comp., Inc, 2001. 
[8] B. Trilling dan P. Hood, Learning, Technology and Education Reform in Knowledge Area, WestEd: Educational Technology, 1999.

[9] [9] Tucson, A Z 2009 The Partnership for 21st Century Skills has developed a vision for student success in the new global economy. (177 N. Church Avenue, Suite 305 Tucson).

[10] T. Riddel, "Critical Asumptions: Thinking Critically About Critical Thinking", Journal of Nursing Education, vol. 46, no.3, 2007.

[11] O. B. Z. Assaraf and O. Nir, "Development of System Thinking Skills", Journal of Research in Science Teaching, vol. 42, no. 5, 2005.
[12] J. B. Harris and M. J. Hofer, "Technological Pedagogical Content Knowledge in Action: A Descriptive Study of Secondary Teachers' Curriculum-Based, Technology-Related Instructional Planning", Journal of Research on Technology in Education, vol. 3, no. 3, 2011.

[13] C. S. Chai, J. H. L. Koh, and C. C. Tsai, "A Review of Technological Pedagogical Content Knowledge", Educational Technology \& Society, vol. 16, no. 2, 2013.

[14] G. N. Masters and M. Forster, Developmental assessment, Victoria: ACER, 2008. 